\title{
The Chinese Tributary System and Traditional International Order in East Asia during the Ming and Qing Dynasties from the Sixteenth to Nineteenth Century
}

\author{
Chen Shangsheng 陳尚勝 \\ Professor of History, Shandong University, China \\ chensh@sdu.edu.cn
}

\begin{abstract}
Throughout the history of East Asia, various polities in modern-day Korea, Japan, and Vietnam accepted investitures bestowed by the Chinese royal court. Many of these states also established their own vassal structures based on this tributary system. In light of this, it would be more accurate to describe the traditional international order of East Asia as a system of investitures and tributes, an "investiture-tribute system." The significance of this system is the royal court being revered by its tributaries, which acknowledge it as the superior power. Looking at the vassal relationship between the Ming [1368-1644] and Qing [1644-1911] courts and the states of Joseon 朝鮮, Ryukyu 琉球, and Vietnam under various names, it is clear that the tributary system was a basic mechanism that facilitated bilateral trade, cultural exchange, border control, and judicial cooperation. Moreover, when vassal states encountered threats to their national security, the Chinese government assisted them with diplomatic and military resources befitting its position as the imperial court. Yet, although the tributary system enabled a relationship in which the royal court enjoyed a position of superiority and its vassal states an inferior one, none of the vassal states formed an alliance that revolved around the Chinese empire. Hence, in the near-modern period, the system struggled to contend with both the great world powers that made use of the treaty system and the expansion of Japan in East Asia.
\end{abstract}

\section{Keywords}

investiture - Japan - Korea - Ryukyu - tribute - Vietnam 
The term "East Asia" as used in this paper refers to the cultural sphere made up of the various regions that share the Chinese writing system, including China and the numerous vassal states that occupied modern-day Korea, Japan, and Vietnam. Research on the traditional international order in this region began with the American scholar John K. Fairbank [1907-1991]. Fairbank organized two seminars in 1963 and 1965 that discussed international order in East Asia and the world order of China respectively. He also suggested that the tributary system could be a basic lens through which these two questions could be analyzed. ${ }^{1}$ Thereafter, the system became the mainstream focal point of Western scholarship on the foreign relations of the Qing dynasty [1644-1911]. ${ }^{2}$ In recent years, Chinese scholars have also followed and published on this topic. Most argue that the traditional international order in East Asia was maintained through the tributary system. Moreover, researchers have discussed not only the historical significance of the system but also its transformation in response to modernity. ${ }^{3}$ Admittedly, to determine whether the traditional international

1 Fairbank edited and published the main papers of those seminars. See John K. Fairbank, The Chinese World Order: Traditional China's Foreign Relations (Cambridge: Harvard University Press, 1968). This publication features papers on premodern China and its relationship with tributaries and Western powers by scholars such as Hae-Jong Chun, Ta-tuan Ch'en, Truong Buu Lam, Joseph Fletcher, John E. Wills, Jr., and David Farquhar.

2 For more works on this topic, see J. L. Cranmer-Byng, "The Chinese Perception of a World Order," International Journal 24, no. 1 (1969); Nigel Cameron, Barbarians and Mandarins (Chicago: University of Chicago Press, 1970); Morris Rossabi, China and Inner Asia: From 1368 to the Present Day (London: Pica Press, 1975); Sarasin Virphol, Tribute and Profit: Sino-Siamese Trade, 1652-1853 (Cambridge: Harvard University Press, 1977); Jonathan Spence and John Wills, Jr., ed., From Ming to Qing: Conquest, Region and Continuity in Seventeenth-Century China (New Haven: Yale University Press, 1979); Kim Key-Hiuk, The Last Phase of the East Asian World Order: Korea, Japan, and the Chinese Empire, 1860-1882 (Berkeley: University of California Press, 1981); Aubery Singer, The Lion and the Dragon: The Story of the First British Embassy to the Court of the Emperor Qianlong in Peking 1792-94 (London: Barrie \& Jenkins, 1992); Alain Peyrefitte, Tingzhi de diguo 停滯的帝國 [The Immobile Empire], trans. Wang Guoqing 王國卿 (Shanghai: Sanlian shudian, 1993); Robert Bikers, ed., Ritual \& Diplomacy: The Macartney Mission to China 1792-1794 (London: British Association of Chinese Studies and Wellsweep Press, 1993).

3 For the purposes of this paper, the "traditional international order in East Asia" refers to the international order centered on the tributary system and the investiture-tribute relationship that existed before China's acceptance of the Western treaty system. For more information, see Shang Huipeng 尚會鵬, "Lunren yu tianxia: jiedu yi chaogong tixi wei hexin de gudai dongya guoji zhixu 倫人與天下:解讀以朝貢體系為核心的古代東亞國際秩 序 ['Lunren' and 'Tianxia': Deciphering the International Order of Ancient East Asia with the Tributary System at Its Core],” Guoji zhengzhi yanjiu 國際政治研究, no. 2 (2009); Jeong Yong Hwa 鄭容和, “Cong zhoubian shijiao lai kan chaogong guanxi: Chaoxian wangchao dui chaogong tixi de renshi he liyong 從周邊視角來看朝貢關係:朝鮮王朝對朝貢體系的認 識和利用 [Viewing the Tributary Relationship from a Peripheral Perspective: The Joseon Dynasty's Understanding and Utilization of the Tributary System]," Guoji zhengzhi yanjiu, 
order in East Asia was indeed constructed through the tributary system, it is necessary to examine the historicity of the tributary system that the Chinese empire enacted with neighboring polities in East Asia. However, it is perhaps even more important to consider whether the vassal states in modern-day Korea, Japan, and Vietnam recognized and adopted this mode of exchange in their handling of foreign affairs. If this recognition and adoption took place, it would then be essential to investigate whether the tributary system played a protective role in the traditional international order in East Asia, particularly in terms of regional security. Such an investigation would be bound up with important questions relating to historicity and modernity in the context of the tributary system. Thus, this article focuses on the period from the sixteenth to the nineteenth century and discusses how the Ming [1368-1644] and Qing courts used the tributary system to handle bilateral relations with, and regional security issues regarding, their various neighboring polities.

\section{Recognition of China's Tributary System by Neighboring States}

The academic consensus that China's tributary system was a basic way for the imperial court to handle political relations with neighboring vassal states has come under criticism in recent years. The argument posits that the system was in fact a kind of imaginary alliance, essentially a product of wishful thinking by the imperial court. ${ }^{4}$ Hence, it is necessary to examine how vassal states in modern-day Korea, Japan, and Vietnam reacted to the system and whether they accepted it.

Historical records indicate that the tributary system ${ }^{5}$ as a means of conducting foreign relations originated in the Western Han 西漢 [2O2 BCE-8] dynasty. According to the Records of the Grand Historian [Shiji 史記], when Liu Bang

no. 1 (2006); Fu Baichen 付百臣, “Lüelun Riben zai Dongya chaogong tixi zhong de juese he zuoyong 略論日本在東亞朝貢體系中的角色和作用 [A Brief Discussion on the Role and Function of Japan in the East Asian Tributary System]," Shehui kexue zhanxian 社會科學戰 線, no. 6 (2007); Zhou Fangyin 周方銀 and Gao Cheng 高程, ed., Dongya zhixu: guannian zhidu yu zhanlüe 東亞秩序:觀念、制度與戰略 [East Asian Order: Concepts, Systems, and Strategies] (Beijing: Shehui kexue wenxian chubanshe, 2012).

4 Zhuang Guotu 莊國土, "Lüelun chaogong zhidu de xuhuan: yi gudai Zhongguo yu Dongnanya de chaogong guanxi wei li 略論朝貢制度的虛幻: 以古代中國與東南亞的朝 貢關係為例 [A Brief Discussion on the Illusion of the Tributary System as Demonstrated by the Tributary Relations between China and East Asia during Antiquity]," Nanyang wenti yanjiu 南洋問題研究, no. 3 (2005).

5 The tributary system originated with the tributes that were made to the emperors of the Zhou dynasty [1046-256 вСE]. Thereafter, the practice spread to vassal states both within and outside the imperial domain. However, this paper focuses primarily on tributes made by vassals outside the Chinese empire. 
劉邦 [r. 207-195 BCE] first brought about the unification of the realms, he did not send troops to pacify the independent Nam Viet 南越, which had been established by Triệu Đà 趙伦 [240-137 BCE] during the chaos that ensued at the end of the Qin [221-207 вCE] dynasty. Instead, in 196 вСЕ he sent Lu Jia 陸賈 [240-17O BCE] to visit Zhao Tuo and bestow upon him the title of "king of Nam Viet," with the aim of brokering peace on the periphery. ${ }^{6}$ The Book of Han [Hanshu 漢書] also records that Liu Bang asked Lu Jia to receive the imperial seal and tassel and that Zhao Tuo made obeisance, acknowledging that he was an imperial subject. ${ }^{7}$ Early in the reign of Emperor Wu of Han 漢武帝 [r. 141-87 BCE], Zhao Tuo even sent his crown prince to go to Chang'an 長安 as his bodyguard. Later in the emperor's reign, Zhao Tuo requested that his kingdom fall under imperial subordination and that its designation be changed from "outer vassal" [waichen 外臣] to “inner vassal” [neichen 內臣].

Consider, also, the historical context of the Korean Peninsula. According to the Records of the Grand Historian, Wei Man 衛滿 [Wi Man, fl. 194], originally from the Han dynasty [2O2 BCE-220] kingdom of Yan 燕, ordered troops to attack the government at Gojoseon 古朝鮮 and establish a new regime with him as king, called Wiman Joseon 衛滿朝鮮 [197-107 BCE]. These events coincided with the unification of China by the Han dynasty. It is recorded that "the Liaodong governor made an agreement with Wei Man, making him an 'outer vassal' to defend against the outer barbarians and thwart border raids; meanwhile, the barbarian chieftains wished to enter the imperial realm to pay tribute to the Son of Heaven, and they were not prohibited." ${ }^{8}$ The essential duties of "outer vassals" included not only sending tribute missions to the Han court but also refraining from preventing barbarian chieftains from seeking an audience with the emperor. At the end of the second century вСЕ, a number of high-ranking military officers who were guarding the frontiers were assassinated in conflicts between the people of Wiman Joseon and the Han dynasty. In response, Emperor Wu of Han raised an army to destroy Wiman Joseon and immediately established the Four Commanderies of Han [Sagun 漢四郡] in the northern Korean Peninsula, including the Lelang [Nangnang 樂浪] Commandery. ${ }^{9}$ Subsequently, the Korean tribes in the southern peninsula submitted to the rule of the Han court and the might of the Cao Wei 曹魏 [213-266]

6 See Sima Qian 司馬遷, “Nanyue liezhuan 南越列傳 [The Biographies of the Southern Yue]," in Shiji 史記 [Records of the Grand Historian] (Beijing: Zhonghua shuju, 2000), 113.2265.

7 Ban Gu 班固, “Gaodi benji 高帝本紀 [The Basic Annals of Emperor Han Gaozu]," in Hanshu 漢書 [The History of the Former Han Dynasty], annot. Yan Shigu 顏師古 (Beijing: Zhonghua shuju, 2000), 1.53.

8 Sima Qian 司馬遷, “Chaoxian liezhuan 朝鮮列傳 [Biographies of the Joseon]," in Shiji, 115.2278 .

9 Ban Gu, “Chaoxian zhuan 朝鮮傳 [Account of Joseon]," in Hanshu, 95.2851-52. 
regime. ${ }^{10}$ The Western Jin 西晉 [265-316] and Eastern Jin 東晉 [317-420] dynasties, the Northern and Southern dynasties 南北朝 [420-589], and the Sui 隋 [581-619] and Tang [618-907] dynasties witnessed the emergence of the Three Kingdoms of Korea 朝鮮三國時代 [ca. 57 BCE-668]—namely, Goguryeo 高句麗, Baekje 百濟, and Silla 新羅. These three states all paid tribute to the Chinese imperial court. ${ }^{11}$ For instance, Silla was able to bring about the destruction of Baekje and Goguryeo in 660 and 668 respectively ${ }^{12}$ through tributes to the Tang court and the military alliances with the Chinese that those tributes achieved. Goguryeo also submitted and paid tribute to various Chinese courts, including the Later Tang [923-936], Later Jin [936-947], Later Han [947-951], and Later Zhou [951-96o], as well as the Northern Song [96o-1127], Liao [907-1125], Jin [1115-1234], Yuan [1271-1368], and Ming dynasties. On account of this, its kings were bestowed with investitures. ${ }^{13}$ After the founding of the Joseon dynasty 朝鮮王朝 [1392-1897], its rulers also submitted and paid tribute to the Ming and Qing courts. After the Qing lost the First Sino-Japanese War 甲午戰爭 [1894-1895], Japan abolished the Sino-Korean tributary system through the Treaty of Shimonoseki 馬關條約. ${ }^{14}$ These facts demonstrate that the various polities on the Korean Peninsula accepted the tributary system set up by the Chinese empire and that they carried out political exchanges with China in their role as vassal states.

These Korean polities also used the tributary system as a way to maintain order with the smaller tribes on their periphery. At the beginning of the reign of Emperor Wu, Wiman Joseon obtained military might and resources, overthrew small border states, and acquired territory that expanded it by several

10 Chen Shou 陳壽, “Dongyi zhuan 東夷傳 [Biographies of the Eastern Barbarians], in San guo zhi 三國志 [Records of the Three Kingdoms], annot. Pei Songzhi 裴松之 (Beijing: Zhonghua shuju, 2000), 30.630.

11 Chen Shangsheng 陳尚勝, “Fenlie shidai de waijiao jingzheng: Wei-Jin Nan-Bei chao shiqi de Zhong-Han guanxi shuping 分裂時代的外交競爭:魏晉南北朝時期的中韓 關係述評 [Diplomatic Competition in an Age of Division: Reviewing the Relationship between China and Korea during the Wei, Jin, and Northern and Southern Dynasties]," in Hanguoxue lunwenji 韓國學論文集 [Collected Papers on Korean Studies], vol. 6, ed. Beijing daxue Hanguoxue yanjiu zhongxin 北京大學韓國學研究中心 (Beijing: Xinhua chubanshe, 1997).

12 Liu Xu 劉朐 et al., "Dongyi liezhuan 東夷列傳 [Biographies of the Eastern Barbarians]," in Jiu Tang shu 舊唐書 [Old Book of Tang] (Beijing: Zhonghua shuju, 200o), 199.3619-62.

13 Jeong In Ji 鄭麟趾, “Shijia 世家 [Hereditary Houses]," in Gaoli shi 高麗史 [A History of Korea] (Tokyo: Kokusho kankōkai, 1908), 1-70o.

14 Wang Tieya 王鐵崖, ed., Zhongwai jiu yuezhang huibian 中外舊約章彙編 [A Compilation of Old International Treaties between China and Other Countries] (Beijing: Sanlian shudian, 1957), 1.614. 
thousand $l i{ }^{15}$ Henceforth, tribes such as the Jurchens 女真 and the Mongols 蒙古 offered protection to the states of Silla and Goguryeo, and the tributes that the tribes paid also enabled political exchanges. ${ }^{16}$ In its waning period, Goguryeo took advantage of the dynastic transition between the Yuan and Ming dynasties, and the civil unrest in northeastern China, to expand its borders to the north and recruit Jurchen tribes to defend its periphery, ${ }^{17}$ a practice that continued into the Joseon dynasty. Not until Aisin-Gioro Nurhaci 愛新覺羅·努爾哈赤 [1559-1626] united the various Jurchen tribes and launched attacks on the Ming and Joseon regimes did this political relationship structure change. ${ }^{18}$ The Joseon also took advantage of the tributary system to carry out political exchanges with Tsushima 對馬 and Ryukyu 琉球, with the aim of constructing a vassal-like system of their own for conducting foreign affairs. ${ }^{19}$

Japan did not begin to engage in political exchange with China until the Han dynasty established the Lelang Commandery. ${ }^{20}$ According to historical records, Japan, called Wonuguo 倭奴國, sent an envoy to China in $57 \mathrm{CE}$. The Han Emperor Guangwu 漢光武 [r. 25-57] bestowed on him an official seal made of gold adorned with a tassel. Amazingly, this seal was discovered in 1784 on Shika Island 志賀島, Japan. Engraved on the seal are the words “King of the Na state of the Wa of the Han dynasty” [hanweinu guowang 漢委奴國王]. ${ }^{21}$ This artifact demonstrates that Japan had accepted the tributary system of the Han dynasty by that time. Thereafter, Japan regularly paid tributes to China. For example, the state of Yamatai-koku 邪馬台国 [c. first century-c. third century] paid tribute to Cao Wei, and during the Asuka 飛鳥 period [600-710], Nara 奈良 period [710-794], and early Heian 平安 period [794-1184], the state of Wa paid tribute to the Tang court. ${ }^{22}$ Japan did not pay tribute to the Song [96o-1279] and

\footnotetext{
15 Ban Gu, "Chaoxian zhuan," 2851.

16 Lee Man Un 李萬運, “Jiaopin kao 交聘考 [Examinations on Exchanges of Diplomatic Missions]," in Zengbu wenxian beikao 增補文獻備考 [Reference on Supplementary Documents] (Seoul: Myeongmundang, 1959).

17 Jeong In Ji, “Gongrang wang shijia 恭讓王世家 [The House of Gongrang], in Gaoli shi, 69 .

18 Yu Xiaoguang 於曉光, “Mingchao yu Chaoxian weirao Nüzhenren de jiaoshe wenti yanjiu 明朝與朝鮮圍繞女真人的交涉問題研究 (1368-1619) [Research on Diplomatic Representations between the Ming Imperial Court and Korea Regarding the Jurchens]” (PhD diss., Shandong University, 2006).

19 Kenneth R. Robinson, "Centering the King Chosõn: Aspects of Korean Maritime Diplomacy," Journal of Asian Studies 59, no. 1 (February 2000).

$20 \quad$ Ban Gu, “Dilizhi xia 地理志 [Treatise on Terrestrial Organization]," in Hanshu, 28.1322.

21 Kimiya Yasuhiko 木宮泰彥, Ri-Zhong wenhua jiaoliu shi 日中文化交流史 [A History of Cultural Exchange between Japan and China ], trans. Hu Xinian 胡錫年 (Beijing: Shangwu yinshuguan, 1980), 12.

22 Chen Shou, "Dongyi zhuan," 3o.631; Liu Xu, "Dongyi liezhuan," 1999.3619-62.
} 
Yuan courts during the mid- to late Heian period and the Kamakura 鎌倉 幕府 period [1069-1333]. However, during the Nanboku-chō 南北朝 period [1334-1392] and the reign of the Muromachi shogunate 室町幕府 [1392-1573], Japan did pay tribute to the Ming court. ${ }^{23}$

Nonetheless, after the Azuchi-Momoyama 安土桃山 period [1573-160o], not only did Japan refuse to submit and pay tribute to China but the preeminent daimyo, Toyotomi Hideyoshi 豊臣秀吉 [1537-1598], also used the tributary system to construct a similar system of order with non-Japanese ethnic groups. ${ }^{24}$ In 1588, Hideyoshi sent an official letter to the king of Ryukyu Shō Ei 尚永 [1559-1588] via the daimyo of Satsuma 薩摩 Province Shimazu Yoshihisa 島 津義久 [1533-1611], demanding that the king pay tribute to Japan. ${ }^{25}$ In 1591 , Hideyoshi entrusted merchants to assist him with delivering a letter to Luzon 呂宋 (in the present-day Philippines). In the letter, Hideyoshi demanded that Luzon pay tribute to Japan and warned he would wage a punitive expedition against the island should it fail to comply in a timely fashion. ${ }^{26}$ In 1592, Hideyoshi issued an imperial edict to Taiwan, urging the island to surrender to Japan. ${ }^{27}$ Evidently, these actions by Hideyoshi constitute an attempt to bring about an international political order in which Japan would play the dominant role.

From 1592 to 1598, Hideyoshi launched two invasions of Korea, known in Japanese as the Bunroku 文禄 and Keichō 慶長 Campaigns. ${ }^{28}$ Japan intended to use Korea as a springboard from which to attack the Ming and hoped that it could replace China as the decisive factor in the East Asian international order. Japan even proposed candidates for "prime minister of China" after

23 Zhang Tingyu 張廷玉 et al., “Riben zhuan 日本傳 [The Biography of Japan]," in Mingshi 明史 [The Official History of the Ming Dynasty] (Beijing: Zhonghua shuju, 20oo), vol. 322.

24 Chen Wenshou 陳文壽, Jinshi chuqi Riben yu Hua-Yizhixu yanjiu 近世初期日本與華夷 秩序研究 [Research on Japan and Hua-Yi Order during the Early Modern Period] (Hong Kong: Xianggang shehui kexue chubanshe, 2002), 33-55.

25 Ban Nobutomo 伴信友, “Zhongwai jingwei zhuan 中外經緯傳 [Chinese and Foreign State Governance Traditions], in Ashita kankei-shi no kenkyū 明日関係史の研究 [Research on Relations between the Ming Dynasty and Japan], ed. Zheng Liangsheng 鄭樑 生 (Tokyo: Yuzankaku, 1995), 455 .

26 Murakami Naojirō 村上直次郎, "Ruson no nyūkō o unagashitaru Hideyoshi no shokan ni tsuite 呂宋の入貢を促したる秀吉の書翰について [On Correspondence by Hideyoshi Urging Luzon to Offer Tributes]," in Ashita kankei-shi no kenkyū, 462.

27 Suga Masatomo 菅政友, "Yutaka taikō oku Taiwan bun 豊太閤贈臺灣文 [Toyotomi Hideyoshi's writings to Taiwan]," in Ooyashima zasshi 大八洲雜誌, no. 27, quoted from Ashita kankei-shi no kenkyū, 463 .

28 These designations derive from the reign-era names of the emperors in Japan. See Fan Shuzhi 樊樹志. “Wanli nianjian de Chaoxian zhanzheng 萬曆年間的朝鮮戰爭 [Military Conflict in Korea during the Reign of the Wanli Emperor]," Fudan xuebao 復旦 學報, no. 6 (2003). 
the Japanese occupation. ${ }^{29}$ After conflict ended among Japan, China, and Korea, Tokugawa Ieyasu 徳川家康 [1543-1616] became the first shoggun in the Tokugawa shogunate in Japan. Because Hideyoshi had been unsuccessful in invading Korea, Ieyasu changed Japan's foreign expansion strategy. In 16o9, he compelled King Shō Nei 尚寧 [1589-1620] of Ryukyu to submit and pay tribute to Satsuma Domain. He hoped that if Korea and Ryukyu both submitted and paid tribute to Japan, then the leaders of the polities of Annam 安南 (modernday Vietnam), Cochin 交趾 and Champa 占城 (both mostly part of Vietnam), Siam 暹羅 (the former name of Thailand), Luzon (the most northerly and largest island in the Philippines), Xiyang 西洋 (a general term for Southeast Asia), and Cambodia 柬埔寨 would send tribute missions to Japan..$^{30}$

Even after Vietnam broke away from the administration of China and established itself as an independent state, it still submitted and paid tribute to the subsequent courts of the Chinese empire. The Đinh 丁 [968-98o], Early Lê 前黎 [980-1009], Later Lý 後李 [1009-1225], Trần 陳 [1225-1400], Hồ 胡 [1400-1407], Later Lê 後黎 [1428-1789], Tây Sơn 西山 [1789-1801], and Nguyễn 阮 [1802-1945] dynasties all used the tributary system to engage in political exchanges with the Song, Yuan, Ming, and Qing dynasties. The Vietnamese rulers also used the system to carry out political exchanges with small neighboring tribes and states, with the aim of establishing a regional order centered on Vietnam. ${ }^{31}$

The Ryukyu kingdom began paying tribute to the Chinese empire much later than these three states. Not until the fifth year of the reign of the Hongwu 洪武 emperor [r. 1368-1398] did the kingdom pay tribute to the Chinese court, having received an imperial edict. ${ }^{32}$ Thereupon, the King of Ryukyu was required by the Ming courts, and later the Qing, to pay tribute once every two years.

29 Fukuo Takeichirō 福尾猛市郎, ed., Nipponshi shiryō shūsei 日本史史料集成 $[A$ Collection of Historical Materials on Japanese History] (Tokyo: Daiichi gakushūsha, 1980), 16 o.

Kyōto shiseki-kai 京都史蹟會, ed., Hayashi Razan bunshū 林羅山文集 [Collected Works of Hayashi Razan] (Kyoto: Heian kōkogaku-kai, 1930), 13 o.

31 Phan Thúc Trực 潘叔直, ed., Guoshi yibian: Mingming zhengyao: Rouyuan 國史遺編.明 命政要·柔遠 [Remnants of the History of the Nation: Political Events of the Ming Dynasty: Pacification of the Distant Regions] (Hong Kong: New Asia Institute of Advanced Chinese Studies, the Chinese University of Hong Kong, 1965), 312, quoted from Han Dongyu 韓 東育, “Hua-Yi zhixu de Dongya goujia yu zijieti neiqing 華夷秩序的東亞構架與自解 體內情 [The Structure of 'Hua-Yi Order' in East Asia and How It Self-Disintegrated]," in Cong zhoubian kan Zhongguo 從周邊看中國 [Viewing China From the Peripheries], ed., Fudan daxue wenshi yanjiuyuan 復旦大學文史研究院 (Beijing: Zhonghua shuju, 2009), 82.

32 “Taizu shilu 太祖實錄 [The Veritable Records of the Founding Ancestor]," in Ming shilu 明實錄 [The Veritable Records of the Ming Dynasty] (Taipei: Zhongyang yanjiuyuan lishi yuyan yanjiusuo, 1962), 1317 . 
However, Ryukyu repeatedly sent additional vessels to Fujian province under the guise of paying tribute. This practice continued until the fifth year of the Guangxu 光緒 emperor [r. 1875-19o8] of the Qing dynasty, when Ryukyu was annexed by Japan. The Ryukyu royal family actively paid tribute to the Chinese imperial court undoubtedly because of important economic and political interests: financial interests and national security respectively. ${ }^{33}$ Notably, these considerations were not unique to the Ryukyu kingdom. From the perspective of the various political regimes in modern-day Korea and Vietnam, a political relationship between them and the various Chinese dynasties could be obtained through the tributary system. With the recognition of the powerful Chinese empire, the regimes had the means to survive and defend themselves. It was also possible for them to obtain external legitimacy for their rule through this relationship. It has been suggested that the tributaries paid tribute as a way of obtaining trade opportunities from China. ${ }^{34}$ In fact, with the border trade system implemented by the Song, Liao, Jin, Yuan, and Qing dynasties, these states were able to obtain trade opportunities through private channels. Obviously, this does not explain why Korea and Vietnam were motivated for commercial reasons to pay tribute to the Chinese. This motivation only affected Japanese tribute to the Sui and Tang courts, which was paid to introduce Chinese culture to Japan in order to effect social change, and the tributes paid by the Muromachi shogunate to the Ming to further Japan's economic interests. ${ }^{35}$ After civil maritime trade between China and Japan was initiated, the Japanese found it difficult to continue paying tribute to the Chinese empire. This demonstrates that, although the Chinese tributary system was adopted by China's neighbors in East Asia, the motivations driving Korea, Japan, Vietnam, and Ryukyu were different. Therefore, by the sixteenth century Japan had already exited the tributary system, whereas Ryukyu, Vietnam,

33 Miyata Toshihiko 宮田俊彥, Ryūmin Ryūshin kōshō-shi no kenkyū 琉明・琉清交渉史 の研究 [Research on the History of Diplomatic Representations between Ryukyu and the Ming and Qing Courts] (Tokyo: Bungaku shuppan, 1996), 277-84; Xie Bizhen 謝必震, Ming-Qing Zhong-Liu hanghai maoyi yanjiu 明清中琉航海貿易研究 [Research into Ryukyu Navigation and Trade during the Ming and Qing Dynasties] (Beijing: Haiyang chubanshe, 2004), 54-57, 155-59.

34 Wang Cungang 王存綱 and Liu Han 劉涵, “Chaogong tixi xia gudai Dongya zhixu xingcheng yu weixi de neizai luoji 朝貢體系下古代東亞秩序形成與維繫的內在邏 輯 [The Internal Logic behind the Formation and Maintenance of Order in East Asia during Antiquity under the Tributary System]," Guoji anquan yanjiu 國際安全研究, no. 4 (2013).

35 Zhang Shengzhen 張聲振 and Guo Hongmao 郭洪茂, Zhong-Ri guanxishi 中日關係史 [A History of Sino-Japanese Relations] (Beijing: Shehui kexue wenxian chubanshe, 2006), 104-7, 312. 
and Korea were forced to stop paying tribute to the Qing under the influence of Japan and France.

The previous section demonstrated that the tributary system facilitated political exchange in the Chinese cultural sphere of East Asia and that the vassal states of China used the system to construct their own self-dominating modes of international order. In light of this, what designation should be given to this mode of international order in East Asia constructed through a tribute system? Many different terms have been used by scholars, which has led to inconsistency in the literature. Many have simply called it a "tributary system"; 36 others have opted for “Hua-Yi 華夷 order,"37 or “Huaxia 華夏 order." ${ }^{38}$ Japanese scholars, in response to the "tributary trade system" theory, have also proposed the "mutual trade system" theory, ${ }^{39}$ while others have suggested the theory of a Tianchao 天朝 system. ${ }^{40}$ Evidently, in considering the issue of the traditional international order in East Asia, it is necessary to discuss the various system designations that have been proposed.

$36 \quad$ The concept of the "tributary system" was first proposed by John K. Fairbank and Yang Lien-sheng 楊聯陸; see John K. Fairbank, “On the Ch'ing Tributary System," Journal of Asiatic Studies 6, no. 2 (1941). However, the term was used primarily to describe relations between the Qing court and foreign states. Hamashita Takeshi proposed the concept of "tributary trade system” in Hamashita Takeshi 濱下武志, Zhu Yingui 朱蔭貴, and Ouyang Fei 歐陽菲, trans., Jindai Zhongguo de guoji qiji: Chaogong maoyi tixi yu jindai Yazhou jingjiquan 近代中國的國際契機:朝貢貿易體係與近代亞洲經濟圈 [International Opportunities in Modern China: The Tributary Trade System and the Modern Asian Economic Zone] (Beijing: Zhongguo shehui kexue chubanshe, 1999).

He Fangchuan 何芳川, “Hua-Yi zhixu lun 華夷秩序論 ['Hua-Yi order' theory]," Beijing daxue xuebao 北京大學學報, no. 6 (1998); Han Dongyu, "Hua-Yi zhixu de Dongya goujia yu zijieti neiqing," 79-9o.

38 Huang Zhilian 黃枝連, Yazhou de Huaxia zhixu: Zhongguo yu Yazhou guojia guanxi xingtai lun 亞洲的華夏秩序: 中國與亞洲國家關係形態論 [Huaxia Order in Asia: A Morphological Theory on Relations between China and Other Asian Countries] (Beijing: Zhongguo renmin daxue chubanshe, 1992).

39 Iwai Shigeki 岩井茂樹, “16-18 shiji dongya de guoji shangye yu hushi tizhi 16-18 世紀 東亞的國際商業與互市體制 [The International Business and Mutual Trade System in East Asia from the Sixteenth to Eighteenth Century]," Higashi-Ajia kenkyū 東アジア研 究 46 (2006).

40 Danjō Hiroshi 檀上寛, Akiyo kaikin = chōkō shisutemu to Ka-I chitsujo 明代海禁=朝貢シ ステムと華夷秩序 [The Ming-Dynasty Ban on Maritime Trade, the Tributary System and Hua-Yi Order] (Kyoto: Kyoto University Academic Press, 2013). 
What is meant by the "traditional international order in East Asia" is the relatively stable relationship models, structures, and states formed by the various premodern polities in East Asia during processes of exchange, with particular emphasis on the connection between its relationship structure and relations between neighboring states. Although the "tributary system" theory advocated by most scholars posits that the tributary system was the main way in which the Chinese empire maintained political relations with its neighbors in East Asia, it focuses only on the core, international system of the dominant state, as opposed to the structure of the traditional political relationship between the dominant state and its neighbors. The term "relationship" used here refers to an association of two or more things. However, in the "tributary system" theory, tributes are perceived as only one-way exchanges that the dominant state expects from the neighboring state and thus fails to explain the two-way nature of the relationship.

Many treatises have characterized the political relationship between China and its neighboring states under the tributary system as one of suzerainty. However, it would not be historically accurate to claim that this was a constant state and ignore the realities in particular periods. Although historical documents have always referred to China's tributary states as vassals, the Chinese empire always referred to itself as the Celestial Empire [tianchao 天朝] during tributes, whereas vassal states referred to China as the superior domain [shangguo 上國] and not a “suzerain," a concept known in Chinese as zongzhuguo 宗 主國. The term "suzerain" has traditionally been applied to the European powers that colonized Asia, Africa, and Latin America. The term "suzerainty" was then used to describe the political power that Western countries had over their colonies. Therefore, the relationship between modern Western countries and their colonial counterparts is often described as consisting of a suzerain and its tributary states. However, considering both the term "suzerainty" and its definition, it would not be historically accurate to use it to describe the political relationship between the dominant Chinese empire and its neighboring states under the tributary system. This is because China generally did not interfere in the internal affairs of its tributaries. ${ }^{41}$ Furthermore, the "vassal system" theory ${ }^{42}$ is somewhat similar to the "tributary system" theory, in that it merely

41 The military and government official Yuan Shikai 袁世凱 [1859-1916] was appointed as a qinchai dachen 欽差大臣 (translated as either imperial commissioner or imperial resident) for residency in Seoul, Joseon-dynasty Korea, but this was an unusual state of affairs in Chinese history.

42 For more information about the "vassal system” theory, see Li Dalong 李大龍, “Butong fanshu tixi de chongzu yu wangchao jiangyu de xingcheng 不同藩屬體系的重組與 王朝疆域的形成 [The Restructuring of Different Vassal Systems and the Formation of Imperial Territories]," Zhongguo bianjiang shidiyanjiu 中國邊疆史地研究, no. 1 (2006); 
points at the intention of the Chinese empire to realize order at its peripheries and fails to denote how relations that informed traditional order in East Asia at the time were structured.

Although the "Hua-Yi order" theory considers the relationship between the two sides, the concept of Hua and Yi is essentially a cognitive problem; a recognition of the self and the other cannot accurately express the interaction between the two in terms of particular patterns, structures, and states. Although the somewhat similar "Hua-Xia order" theory also expresses the dominant ideology of Chinese dynasties to some extent, it fails to express the main behavioral patterns and structures of the relationship between East Asian states.

Although the "mutual trade system" theory demonstrates a model of the relationship between China and foreign states in the Song dynasty and beyond, it is only an economic relations model. Therefore, it ignores or even avoids the political premise of institutional arrangements for such economic relations. After all, the essential function of international order as maintained between different regions is informed by the political relationship between states.

The premise of the "Tianchao system" theory is based on the bias and insufficiency of the "tributary system" and "mutual market system" theories. It is intended to integrate the two but is flawed, as it is focused on the Chinese empire. Even though the Chinese empire played a dominant role in maintaining international order in its region, the concept fails to take into account the other side of the relationship between other states. Moreover, the "Tianchao system" as a term and concept used to describe relations between premodern China and foreign polities was used only in the context of the Qianlong 乾隆 [1711-1799] and Xianfeng 咸豐 [1851-1862] eras of the Qing dynasty. It also has institutional and authoritative connotations. ${ }^{43}$ For those reasons, it would be inappropriate to use a term that is dependent on a particular historical period, or semantically inconsistent, to denote the long-standing foreign relations of the Chinese empire.

Because the traditional international order in East Asia refers mainly to the primary relationship model and structure of political exchanges between

Li Dalong, "Guanyu fanshu tizhi de jige lilun wenti: dui Zhongguo gudai jiangyu lilun fazhan de lilun chanshi 關於藩屬體制的幾個理論問題一對中國古代疆域理論發 展的理論闆釋 [Some Theoretical Issues Related to the Vassal System: A Theoretical Interpretation of the Development of Ancient Chinese Periphery Theory]," Xuexi yu tansuo 學習與探索, no. 4 (2007).

43 Chen Shangsheng, “Qing shi lu zhong de tianchao tizhi kaolun〈清實錄〉中的“天朝 體制’考論 [An Investigation of the 'Celestial System' in the Veritable Records of the Qing Dynasty]," in Ji'nan shixue 暨南史學 [Ji'nan Historiography], ed. Ma Mingda 馬明達 and Ji Zong’an 紀宗安, vol. 9 (Guilin: Guangxi shifan daxue chubanshe, 2014). 
states in the region, in particular China and its neighbors, it is necessary to examine the tributary system as the primary mode of political relations between the Chinese empire and its neighboring states. This then allows an analysis of the relationship structure that was informed by the various states. Generally, when the Chinese empire received tributes from its neighbors, it reciprocated with investitures and tributes. Investitures established a relationship in which the Chinese empire enjoyed superior standing, and tributaries an inferior one. Tributes were economic rewards bestowed upon the tributary states by the imperial court. Through these investitures and tributes, China formed a political relationship with its neighbors, thus achieving regional order in its international relations, as intended. Because the main structure of the traditional international order in East Asia at this time was made up of a system of investitures and tributes, a proper designation for this system is an “investiture-tribute system [fenggong tixi 封貢體系].”

The Qing government stipulated that when foreign tribute missions went to China, relevant documentation first had to be submitted to the viceroy and inspector general [dufu 督撫] at the port of entry for transfer to the court. Furthermore, in addition to tribute affairs, foreigners also had to send official documents to viceroys and inspector generals at the Chinese border, who then read the documentation, discussed its contents, provided a response, and then reported back to the court. Notably, viceroys and inspector generals were not allowed to send official documents to neighboring tributary states without authorization. ${ }^{44}$

According to the Verifications of Collected Texts [Tongwen hui kao 同文彙考], whenever a matter concerning relations between the Qing court and Korea arose, officials were dispatched to the other side to deliver an official document shared between government offices of equal rank [ziwen 咨文] to explain the situation and reach a resolution through cooperation. ${ }^{45}$ The Qing generally issued a ziwen via the the Ministry of Rites [Libu 禮部], although sometimes this was done by the Ministry of Revenue [Hubu 戶部] or the Ministry of War [Bingbu 兵部], depending on the nature of the matter. Meanwhile, the Korean ziwen was issued in the name of the king, and its envoy was known as

44 Daqing huidian: Yongzheng chao 大清會典.雍正朝 [Yongzheng Period in Collected Statutes of the Great Qing], vol. 104 (Beijing: Xianzhuang shuju, 2006).

45 Seung Moon Won 承文院, Tongwen huikao 同文彙考 [Verifications of Collected Texts] (Seoul: Gugsapyeonchan-wiwonhoe, 1978). 
a jaejahaeng 齎咨行, to distinguish it from an ordinary diplomat. ${ }^{46}$ The Korean envoys were usually served by official linguists proficient in Chinese or lowerranking military officers whose titles were lower than those of the official envoys. Unlike the missions of the official envoys, which involved handling the political relationship between the Qing court and Korea and its various rituals, the ziwen envoys were responsible for reporting on specific affairs between the two states, such as requests by the Korean court for almanacs, bilateral trade, border surveys, investigations into cross-border crimes, unlawful cross-border fishing, and maritime disaster relief.

The issue of cross-border crimes in the border areas between China and Korea was a common feature of the ziwen and subsequent consultation between the Qing and Korean courts. During the reign of the Shunzhi 順治 emperor [r. 1643-1661], Koreans crossed the border into China to hunt and collect ginseng. When they were discovered, the Ministry of Revenue sent a ziwen to the Korean court, and the Chinese court sent a special envoy to Korea to represent it at the Korean court. ${ }^{47}$ Not long thereafter, the judicial authorities in the Chinese and Korean courts then prosecuted the offenders through a joint trial. ${ }^{48}$ For serious cases, such as those involving Koreans entering China and committing a homicide, in general the Ministry of Rites issued the ziwen, and Korea responded by dispatching a special envoy to China with a ziwen issued by the king that contained a briefing on the situation. After an imperial decree was issued, both sides sent judicial officers to Fenghuang 鳳凰 or Shengjing 盛京 to conduct the trial or the Koreans held it in Korea. ${ }^{49}$

When Chinese men crossed the border to fish on the Korean coastline, Korea also dispatched special envoys to the Ministry of Rites, and the Chinese court ordered the local government to investigate and address the matter. For

46 For more information on jaejahaeng envoys, see Yue Yang 岳陽, “Qing-Xian guanxi zhong de Chaoxian jizixing yanjiu 清鮮關係中的朝鮮齊諮行研究 [Research into Korean Jaejahaeng Envoys in the Context of Qing-Korean Relations]" (master's thesis, Shandong University, 2010).

47 Seung Moon Won, “Fanyue 犯越," in Tongwen huikao, vol. 49.

48 Seung Moon Won, "Fanyue," vol. 49.

49 Liu Yuewu 柳获武, "Qingdai zhongqi yiqian Zhong-Chao zongfan guanxi xia de sifa yunzuo zhi yanjiu 清代中期以前中朝宗藩關係下的司法運作之研究 [Research into the Judicial Operations of the Chinese Imperial Court in the Context of Pre-Mid Qing-Dynasty Vassal Relations]," Fujian shifan daxue xuebao 福建師範大學學報, no. 2 (2007); Wang Yanjie 王燕傑, “Shixi Qianlong ershijiu nian de Shengjing huishen: jian lun Shengjing huishen yu Fenghuang cheng huishen de chayi 試析乾隆二十九年的 盛京會審:兼論盛京會審與鳳凰城會審的差異 [A Tentative Analysis of the Joint Trials Held in Shengjing in the Twenty-ninth Year of the Reign of the Qianlong Emperor and a Discussion of Differences between the Joint Trials of Shengjing and Those of Fenghuangcheng]," Shehui kexue jikan 社會科學輯刊, no. 4 (2011). 
example, in the second month of the fortieth year of the reign of the Kangxi 康熙 emperor [r. 1661-1722], Korea dispatched an envoy to report that Chinese fishing boats had encroached on their coastal territory. The Ministry of Rites advised the Korean court that, if thereafter people in China encroached on Korean territory by engaging in fishing or trading, the Korean authorities should check the documentation of the relevant boat, the number of people on board, and their names and place of origin. They could then write a report to the Ministry of Rites, which reported to the local government of the fishermen's hometown, which then severely punished the offenders. ${ }^{50}$ In the sixth month, the Korean court informed the Ministry of Rites that fishing boats from Fushan 福山 in Dengzhou 登州 and Jinzhou 金州 in Fengtian 奉天 province were discovered on the Korean coast. Thereupon, the Ministry of Rites ordered local officials to investigate and punish the offenders.

After the Qing court lifted the ban on maritime trade [haijin 海禁], the Ministry of Rites informed Korea that, "regarding those [Chinese merchants] adrift [in Korea after being shipwrecked], those with intact vessels will be repatriated by sea, while those without vessels will be transported to Fenghuang." ${ }^{51}$ In fact, Korea assisted Chinese who had been shipwrecked in Korean waters by helping them to repair vessels that were salvageable and by supporting with food and clothing those who were repatriated. For those who could not repair their boats, the government provided funds for purchasing their goods and registered the shipwrecked merchants' names, ages, place of residence, and cargo. They also dispatched officials to Fenghuang to return them and gave the Ministry of Rites a ziwen from the Korean court that had reported the particulars of the incident. ${ }^{52}$ The Qing court also stipulated that foreigners who had been shipwrecked had to be rescued where they were discovered and provided food and clothing paid for with public funds. Their boats were then repaired, their cargo was returned, and then they were repatriated. As for the repatriation arrangements of Korean shipwrecked merchants whose boats could not make the voyage back to Korea, local officials verified their identities, and the Provincial Surveillance Commission [Anchasi 按察司] of the province where they were found reviewed the case and then transferred it to the Ministry of Rites. The Ministry of Rites then sent a ziwen to the Korean court and repatriated the shipwrecked merchants through the tribute mission.

50 Seung Moon Won, Tongwen huikao, vol. 6o; "Suzong shilu 肅宗實錄 [The Veritable Records of Sukjong]," in Chaoxian wangchao shilu 朝鮮王朝實錄 [The Veritable Records of the Joseon Dynasty], vol. 35, available on the website of the National Institute of Korean History, http://sillok.history.go.kr.

$5^{1} \quad$ "Suzong shilu," vol. 2 .

52 "Suzong shilu," vol. 4 o. 
In a month when Korean had no mission in Beijing, the Ministry of Rites directly sent escorts to Joseon to complete the handover. ${ }^{53}$

Acting out of compassion for the people in the vassal states, in some cases the Qing court arrested looters of Korean shipwrecks. For example, in the second month of the eleventh year of the reign of the Daoguang 道光 emperor [r. 1821-1850], a Korean merchant's shipwreck drifted to Huangyan 黃岩 county, Zhejiang province, and its cargo was looted by a small number of villagers. After the county magistrate heard about the incident, he sent men to take in those who had been aboard the vessel so they could take refuge in the county. He sealed off their remaining cargo for safekeeping and ordered the arrest of five of the looters. He then seized cloth and other belongings from the looters and returned them to the Korean merchants. After receiving a petition from Sun Erzhun 孫爾准, the then一viceroy [zongdu 總督] of Min-Zhe 閩浙, the Daoguang emperor issued an edict ordering additional aid to be given to the Korean merchants and compensation to be paid in advance by Huangyan county for looted items that had not yet been recovered. The emperor also stipulated that the damaged vessels be sold at a fixed price, with the proceeds given to the merchants. Before long, these merchants traveled to Beijing under the escort of local officials. The Ministry of Rites informed the king by a ziwen about the relief given to the merchants and arranged for them to return to Korea with the tribute mission. ${ }^{54}$

The compendium of diplomatic documents collected by the royal government of the Ryukyu kingdom, titled Precious Documents of Successive Generations [Rekidai hōan 歴代宝案], spans 1424 to 1867. Most of these documents are communications between the kingdom and the Ming and Qing courts. These documents contain a large volume of ziwen exchanged between the kings of Ryukyu and the Ministry of Rites and the Provincial Administration

53 Tuo Jin 托津, ed., Qing huidian shili 清會典事例 [Examples of Qing Dynasty Statutes] (Beijing: Zhonghua shuju, 1991); Tang Xiyong 湯熙勇, “Qing shunzhi zhi qianlong shiqi Zhongguo jiuzhu Chaoxian hainanchuan ji piaoliumin de fangfa 清順治至乾隆時期中 國救助朝鮮海難船及漂流民的方法 [How China Provided Relief to Korean Vessels and Individuals Affected by Maritime Disasters from the Reigns of the Shunzhi Emperor to the Qianlong Emperor of the Qing Dynasty]," in Zhongguo haiyang fazhanshi lunwenji 中國海洋發展史論文集 [Collected Papers on the Maritime History of China], vol. 8 (Taipei: Zhongyang yanjiuyuan zhongshan renwen shehui kexue yanjiusuo, 2002).

54 “Qing Xuanzong shilu 清宣宗實錄 [The Veritable History of the Xuanzong Emperor of Qing]," in Qing shilu 清實錄 [The Veritable Records of the Qing Dynasty], vol. 186; Zhongguo di yi lishi dang'anguan 中國第一歷史檔案館, ed., Qingdai Zhong-Chao guanxi dang'an shiliao xubian 清代中朝關係檔案史料續編 [Continuation of Historical Archives on the Relations between China and Korea during the Qing Dynasty] (Beijing: Zhongguo dang'an chubanshe, 1998), 146-47. 
commissioners [buzhengshi 布政使] in Fujian. The ziwen are mainly notices on trade affairs, reports on navigation and shipwrecks, information on maritime crimes, intelligence on pirates who raided the coastlines of China and Korea from the thirteenth to sixteenth centuries, known as wokou [wakō 倭寇], and even reports on the Western powers..$^{55}$

After the establishment of the tributary relationship between the Qing dynasty and the Lê dynasty, the viceroys of Liangguang 兩廣 (modern-day Guangdong and Guangxi provinces) and Yungui 雲貴 (modern-day Yunnan and Guizhou provinces) used ziwen to negotiate with Vietnamese emperors on border trade affairs that affected the two countries and even boundary settlements. During the early reign of the Yongzheng 雍正 emperor [r. 17091722], a land dispute broke out between local officials and chieftains in parts of Vietnam and southern China. The governor of Guangxi, $\mathrm{Li} \mathrm{Fu}$ 李絠 [1675-1750], sent a ziwen to the emperor of Vietnam to negotiate an immediate resolution to the dispute. ${ }^{56}$ The tribal lands in Yunnan, which spanned an area of over a hundred $l i$ 里, were also occupied by the Vietnamese on account of their silver and copper reserves. The governor of Yunnan province Gao Qizhuo 高 其倬 [1676-1738] sent officials to the border to investigate, report what they found to the Chinese court, and keep the emperor of Vietnam informed using a ziwen. This demonstrates that the tributary system was not only the basic means by which either side could stay up to date on bilateral affairs but was also an important mechanism for settling bilateral matters and cooperating on border affairs.

An examination of the initial implementation of the tributary system during the Han dynasty makes it clear that the Chinese empire consistently used the system to develop relationships with foreign states, with the self-serving strategic aim of securing peace and order on its periphery, whether in states such

55 Lidai bao'an 歷代寶案 [Precious Documents of Successive Generations] (Taipei: Guoli Taiwan daxue, 1972).

56 “Guangxi xunfu Li Fu zou duchen yi xingwen Annan guowang zhe 廣西巡撫李紘奏督 臣已行文安南國王摺 [Memorials of Li Fu to the Emperor that Documents have been Sent to the King of Annam]," in Gongzhongdang Yongzhengchao zouzhe 宮中檔雍正朝 奏摺 [Memorials to the Emperor in the Yongzheng Imperial Archives], ed. Guoli gugong bowuyuan gugong wenxian bianji weiyuanhui 國立故宮博物院故宮文獻編輯委員會 (Taipei: Gugong bowuyuan, 1978), 562 . 
as the Nam Viet, the Wiman Joseon, or the Western Regions [Xiyu 西域]. ${ }^{57}$ The system was used for the same purpose during the Qing dynasty as a kind of selfdefense mechanism. ${ }^{58}$ From the perspective of international relations in East Asia, what role did China's tributary system play in the context of regional and international order? Clearly, the essence of the tributary relationship lies in its subordinate nature; the tributary state submits to the imperial court, while the royal court offers tributes, investitures, and protection to the tributary state. In light of this, it is necessary to examine whether the Ming and Qing courts bore their responsibility for protecting the national security of their tributaries.

Consider, for example, the Joseon dynasty, a Korean dynastic kingdom that lasted from 1392 to 1897. In 1592, ${ }^{59}$ Hideyoshi led a large-scale invasion into Korea. As the Japanese army rapidly approached the imperial capital, Korea sent a ziwen to the Ministry of War at the Ming court to provide emergency assistance. ${ }^{60}$ The Ming decided to defend Korea against the Japanese on the Liaodong Peninsula and in Shandong province. ${ }^{61}$ After the troops that the Ming had sent in advance lost their advantage, the Wanli emperor ordered the Korean court to await further assistance by the Ming's main forces. ${ }^{62}$ In the eighth month, the Ming appointed Li Rusong 李如松 [1549-1598] to lead the army as commander in chief to support the Korean military against the Japanese invasion. The Ming army were victorious in Pyongyang 平壤 and Kaesong 開城 but were frustrated in the Battle of Byeokjegwan 碧蹄館之戰, and so had no option but to hold peace talks with the Japanese. However, when the Japanese demanded annexation of Gyeonggi 京畿, Chungcheong 忠 清, Jeolla 全羅, and Gyeongsang 慶尚 provinces, the Ming categorically refused and resolved to safeguard Korea's territorial integrity. In 1597, Japanese mobilization in Korea once again led to the outbreak of war. The Ming immediately appointed the minister of war, Xing Jie 邢玠 [1540-1612], to handle the resistance against the Japanese in Korea, with Ma Gui 麻貴 [1543-1617] and Yang

57 Ban Gu, "Nanyue Chaoxian zhuan 南粤、朝鮮傳 [Biographies of the Southern Yue and Joseon]” and “Xiyue zhuan 西域傳 [Biographies of the Western Regions]," in Hanshu, vol. 95 and vol. 96.

58 Chen Shangsheng, “Shilun Qing qianqi fenggong tixi de jiben tezheng 試論清前期封貢 體系的基本特徵 [A Tentative Discussion on the Basic Features of the Investiture-Tribute System of the Early Qing Dynasty]," Qingshi yanjiu 清史研究, no. 2 (2010).

59 Specifically, this occurred on the thirteenth day of the fourth month of the twenty-fifth year of the reign of King Seonjo of Joseon. In China, it was the twentieth year of the reign of the Wanli emperor of the Ming dynasty.

6o “Xuanzu shilu 宣祖實錄 [The Veritable Records of Seonjo]," in Chaoxian wangchao shilu, vol. 26.

61 “Shenzong shilu 神宗實錄 [The Veritable Records of the Wanli Emperor]," in Ming shilu, vol. 249 .

62 "Shenzong shilu," vol. 25 . 
Gao 楊鎬 [d. 1629] commanding an army 70,0oo strong. By December 1598, the Japanese army was finally expelled from Korea. Soon after the war ended, the Ming government recalled its troops from Korea.

After the establishment of the Meiji government, discussion once again arose in Japanese political circles about invading Korea in what became known as the Seikanron 征韓論, a major debate that centered on whether Japan should launch a punitive expedition against Korea. Initially, the Japanese statesman Kido Takayoshi 木戸孝允 [1833-1877] proposed that Japan establish diplomatic relations with China and Korea, arguing that a punitive expedition against the country could be launched if it continued to be "obstinate" and "disrespectful." In November 1868, Japan sent an envoy to Busan 釜山 to deliver a message from the emperor of Japan. The official in charge of Korea's negotiations with Japan ensured that the message included terms such as "the emperor," "the court," and "decree," leading him to conclude that it implied Korea was a vassal of Japan. He thus refused to accept the Japanese emperor's message, which renewed discussion among the Japanese about invading Korea. Some Japanese believed that, if Japan did not make the first move, Western countries would take Korea before them and that annexing Korea would provide space for their failed seigniors. ${ }^{63}$ In 1875, Japan dispatched its gunboat Un'yō 雲揚 [Rising Cloud] to Korea as a show of force, an incident that eventually enabled them to induce Korea to sign the Treaty of Ganghwa 江華條約 and open up ports at Incheon 仁川 and Wonsan 元山 to Japanese merchants. ${ }^{64}$

Qing court officials were extremely concerned about how to cope with Japanese expansion into Korea. As early as the sixth year of the reign of the Tongzhi 同治 emperor [r. 1862-1874], officials in the Qing government responsible for foreign affairs read in newspapers that Japan was preparing to invade Korea. The Qing court informed Korea that Japan's attempts at aggression should be nipped in the bud. ${ }^{65}$ The Qing was also incredibly concerned about Korea's national security and its "hermit kingdom" policy. The Guangxu emperor ordered Li Hongzhang 李鴻章 [1823-1901] to write to senior Korean official Yi Yu-won 李裕元 [1814-1888] and provide him with advice on how

63 Chen Zhiqi 陳志奇, Zhongguo jindai waijiaoshi 中國近代外交史 [A History of Chinese Foreign Relations in the Modern Era], part 2 (Taipei: Nantian shuju, 2003), 653-54.

64 “Gaozong shilu 高宗實錄 [The Veritable Records of Gojong]," in Chaoxian wangchao shilu, vol. 13 .

65 See Guo Tingyi 郭廷以 and Li Yushu 李艈澍, ed., Qingji Zhong-Ri-Han guanxi shiliao 清季中日韓關係史料 [Historical Records on Relations between the Late Qing, Japan and Korea] (Taipei: Zhongyang yanjiuyuan jindaishi yanjiusuo, 1972), 51-52. 
to proceed. ${ }^{66}$ Under the patient persuasion of Qing officials, Korea's attitude toward foreign trade gradually changed. From the eighth to the tenth year of the reign of the Guangxu emperor, Korea signed trade agreements with a large number of countries, including the United States, China, Britain, Germany, Italy, and Russia. ${ }^{67}$ Despite the weak state of the Chinese empire at the time, the Qing attempted to constrain the Western powers and Japan by inducing Korea to enter into agreements with them. Although Korea was later annexed by Japan, the Qing nonetheless endeavored to fulfill its obligations to maintain Korea's national security.

When the king of Ryukyu discovered that the French planned to colonize his kingdom, he sent a ziwen to the provincial administration commissioner of Fujian informing him of the matter. ${ }^{68}$ Local officials in Fujian promptly informed the Daoguang emperor of the matter. The Qing government ordered Ch'i-ying 耆英 [1787-1858], the viceroy of Liangguang, to represent it with the French envoy stationed in Guangdong. ${ }^{69}$ In the first year of the reign of the Guangxu emperor, Japan announced that it was preparing to annex the kingdom in its "punishment of Ryukyu." The Qing government ordered its diplomatic minister stationed in Japan He Ruzhang 何如璋 [1838-1891] to represent it with Japan. In the ninth month of the fourth year of the reign of the Guangxu emperor, He sent a diplomatic note to the Japanese diplomat Terashima Munenori 寺島宗則 [1832-1893], claiming that Ryukyu was a dependency of China and that China was opposed to Japan's planned invasion and occupation. ${ }^{70}$ In the fifth year of the reign of the Guangxu

66 Guo Tingyi and Li Yushu, Qingji Zhong-Ri-Han guanxi shiliao, 361, 364-69. See also Gu Tinglong 顧廷龍 and Dai Yi 戴逸, ed., Li Hongzhang quanji 李鴻章全集 [The Complete Works of Li Hongzhang] (Hefei: Anhui jiaoyu chubanshe, 2008), 334; Hanguo minzu wenhua tuijin weiyuanhui 韓國民族文化推進委員會, ed., Hanguo wenji congkan 韓國文 集叢刊 [The Collected Works of Korea] (Seoul: Minzu wenhua tuijinhui, 2003).

67 See Guo Tingyi and Li Yushu, Qingji Zhong-Ri-Han guanxi shiliao, 2.552, 679, 694, 3.987-70. See also "Gaozong shilu," vol. 20.

68 Lidai bao'an, 8737-39.

69 Wen Qing 文慶, Jia Zhen 賈楨 and Bao Yun 寶菳 et al., ed., “Chouban yiwu shimo 籌辦夷務始末 [Foreign Affairs of the Late Qing Dynasty],” in Xuxiu siku quanshu 續修四 庫全書 [A Continuation of the Complete Library of the Four Treasuries], Daoguang era 道光朝 (Shanghai: Shanghai guji chubanshe, 1996), 416.73.31-33; Zhang Cunwu 張存武, "Zhongguo dui xifang kuisi Liuqiu de fanying: 1840-186o 中國對西方窺伺琉球的反應: 1840-186o [China's Reaction to the West's Gaze on Ryukyu, 1840-186o]," Jindaishiyanjiusuo jikan 近代史研究所集刊 16 (1987).

70 Riben waijiao wenshu 日本外交文書 [Diplomatic Documents of Japan], 11.271-72, quoted from Qi Qizhang 戚其章, “Riben tunbing Liuqiu yu Zhong-Ri guanyu qiu’an de jiaoshe 日 本吞併琉球與中日關於球案的交涉 [Japan's Annexation of Ryukyu and Diplomatic Representations Made by China and Japan about Ryukyu]," Ji'nan jiaoyu xueyuan xuebao 濟南教育學院學報, no.5 (2000). 
emperor, the Qing sent a cordial invitation to former president of the United States Ulysses S. Grant requesting he serve as mediator between China and Japan. However, the Chinese were ultimately unable to prevent Japanese annexation of the Ryukyu kingdom on account of the weak state of the Qing dynasty.

A similar scenario played out in Vietnam. In 1802, Nguyễn Phúc Ánh 阮福映 [1762-1820], the powerful minister of the Later Lê—a dynasty that had been founded independently in southern Annam-launched a punitive expedition in northern Vietnam that destroyed the Tây Sơn 西山 regime. Thereafter, he proclaimed himself Emperor Gia Long 嘉隆, the first emperor of the Nguyễn dynasty. Not long afterward, Gia Long sent an envoy to the Qing court to pay tribute and request approval of the dynastic name change. The Qing court registered the name Yuenan 越南 (corresponding to modern-day Vietnam) and bestowed investiture upon Gia Long as its ruler. Henceforth, China and Vietnam established investiture-tribute relations of a political nature. Early in the reign of the Tongzhi emperor, remaining members of the secret Heaven and Earth Society [Tiandi hui 天地會] in Guangxi moved into Vietnam. Gia Long requested assistance from the Qing court in pacifying them. The Qing, acknowledging Vietnam as a long-term vassal state, dispatched Su Ziwen 蘇子 文 and Feng Zicai 馮子材 [1818-1903] to lead an army into Vietnam to cooperate with the Vietnamese army in launching a converging attack against them. ${ }^{71}$ At this very moment, France, under the pretense that Vietnam had previously requested assistance from them, continuously invaded and expanded into Cochinchina [Bắc Kì 南圻] and in Tonkin [Nam Kì 北折] fought with Vietnam over the right to navigate the Red River [Sông Hồng 紅河], which rises in Yunnan in southern China and flows through northern Vietnam. These actions ultimately compelled Vietnam to sign a treaty of peace and alliance. ${ }^{72}$ In the fourth year of the reign of the Guangxu emperor, a peasant uprising occurred in northern Vietnam. The then—emperor of Vietnam Nguyễn Phúc Thì 阮福時 [r. 1847-1883] asked the Qing provide military support. The Guangxu emperor responded by ordering Feng Zicai to send troops to suppress the uprising. ${ }^{73}$ Meanwhile, France was considering sending troops to Tonkin. After this was discovered by Zeng Jize 曾紀澤 [1839-189o], the Qing minister to Britain,

71 “Muzong shilu 穆宗實錄 [The Veritable Records of the Tongzhi Emperor]," in Qing shilu, vol. 245. See also Da'nan shilu 大南實錄 [The Veritable Records of the Great South] (Tokyo: Keio Institute of Cultural and Linguistic Studies, 1961).

72 Zhongguo shixuehui 中國史學會, ed., Zhong-Fa zhanzheng 中法戰爭 [The Sino-French War] (Shanghai: Shanghai renmin chubanshe, 1957), 1.379-87.

73 Guo Tingyi 郭廷以 and Wang Yujun 王聿均, ed., Zhong-Fa-Yuenan jiaoshe dang 中法 越南交涉檔 [Archives on Representations Made by China, France and Vietnam] (Taipei: Zhongyang yanjiuyuan jindaishi yanjiusuo, 1962), 1.91 . 
France, and Russia, Zeng conveyed the views of the court to France regarding Vietnam's standing as a vassal state of China. ${ }^{74}$ In the eighth year of the reign of the Guangxu emperor, France sent troops from Cochinchina to the north to attack the Vietnamese, resulting in the fall of Hanoi 河內. The Qing court ordered Lưu Vĩnh Phúc 劉永福 [1837-1917] to lead his Black Flag Army [Quân cờ đen 黑旗軍] to Vietnam to resist the French. The Qing's actions aimed to protect Vietnam as one of its vassal states.

These events demonstrate how the Ming and Qing courts carried out the tributary system when conducting diplomacy with its neighboring states in East Asia. In particular, they provided high levels of assistance to their tributaries at the political and even military level. Therefore, the investiture-tribute relationship in which the Ming and Qing courts played dominant roles was the primary mechanism used to maintain the stability of international order in East Asia. Even if the Ming and Qing courts had been successful in countering challenges to its regional order from other nation-states during the premodern period, after China began to modernize it lacked the ability to cope with Japan's expansion into its neighboring states during the Meiji Restoration 明治維新 [began 1868] as well as the great world powers of the nineteenth and twentieth century. Thus, the international order in East Asia that had once been dominated by the Chinese empire and its investiture-tribute relationships had to give way to a new system of international order instituted by the Western powers.

The tributary system established in East Asia during the Ming and Qing dynasties quickly dissolved when confronted with the Western powers. This was due to the weakness of the Qing regime and its neighboring tributaries and the conspiracy of Western aggression against China. An examination of the international relations system constructed by Western countries clearly reveals the structural defects of the tributary system. The tributary network built and maintained by the regimes of premodern China was made up of many concentric circles, and the relationship between the imperial court and the tributaries was based entirely on unilateral relations. No effective alliance was formed between the two parties. The various states neither cooperated nor supported one another in matters of national security involving the imperial court. Therefore, this tributary system, which was essentially a unilateral

74 Shao Xunzheng 邵循正, Zhong-Fa-Yuenan guanxi shimo 中法越南關係始末 [Relations between China, France and Vietnam] (Shijiazhuang: Hebei jiaoyu chubanshe, 2000). 
relationship, could not withstand the treaty system manifested in the context of multinational cooperation, whose primary purpose was to satisfy the mutual needs of the relevant states. Ultimately, the structural defects of the traditional tributary network meant the system could not meet the needs of regional security and international order in modern East Asia.

However, although ceremonial inequalities existed in the tributary system, which is an important mechanism for maintaining traditional international order in East Asia, the imperial court rarely intervened in the internal affairs of the tributaries. In this way, it could maintain peace and order among the states in the region for long periods. Moreover, the relationship between the imperial court and the tributary states became the basic mechanism for cooperation in bilateral affairs between the Ming and Qing dynasties, as well as their neighboring states. They could conduct trade and cultural exchanges, control the frontiers, and engage in judicial cooperation against cross-border crimes. In addition, after the Ming and Qing dynasties entered into tributary relationships with their neighboring states, the Chinese courts always assumed an obligation to maintain the national security of their tributaries. From this, a case can be made that, to ensure China's stability in the East Asian region, as well as the stability of international order more broadly, the ruler not only had to govern with integrity and benevolence to bring about peace and prosperity but also had to create a mechanism that would enable a rapid response in bilateral and multilateral affairs. Additionally, considerable military might was needed to resist challenges and expansion by hostile forces.

\section{Translated by Carl Gene Fordham}

\section{Works Cited}

Ban Gu 班固. Hanshu 漢書 [The History of the Former Han Dynasty], annot. Yan Shigu 顏師古. Beijing: Zhonghua shuju, 2000.

Bikers, Robert, ed. Ritual \& Diplomacy: The Macartney Mission to China 1792-1794. London: British Association of Chinese Studies and Wellsweep Press, 1993.

Cameron, Nigel. Barbarians and Mandarins. Chicago: University of Chicago Press, 1970. Chaoxian wangchao shilu 朝鮮王朝實錄 [The Veritable Records of the Joseon Dynasty]. Available on the website of the National Institute of Korean History, http://sillok .history.go.kr.

Chen Shangsheng 陳尚勝. "Fenlie shidai de waijiao jingzheng: Wei-Jin Nan-Bei chao shiqi de Zhong-Han guanxi shuping 分裂時代的外交競爭:魏晉南北朝時期的 中韓關係述評 [Diplomatic Competition in an Age of Division: Reviewing the 
Relationship between China and Korea during the Wei, Jin and Northern and Southern Dynasties]." In Hanguoxue lunwenji 韓國學論文集 [Collected Papers on Korean Studies], ed. Beijing daxue hanguoxue yanjiu zhongxin 北京大學韓國學研 究中心, 6.6-14. Beijing: Xinhua chubanshe, 1997.

Chen Shangsheng 陳尚勝. "Qing shi lu zhong de tianchao tizhi kaolun〈清實錄〉中 的 ‘天朝體制” 考論 [An Investigation of the 'Celestial System' in the Veritable Records of the Qing Dynasty].” In Jinan shixue 暨南史學 [Jinan Historiography], ed. Ma Mingda 馬明達 and Ji Zongan 紀宗安, 9.285-305. Guilin: Guangxi shifan daxue chubanshe, 2014.

Chen Shangsheng 陳尚勝. “Shilun Qing qianqi fenggong tixi de jiben tezheng 試論 清前期封貢體系的基本特徵 [A Tentative Discussion on the Basic Features of the Investiture-Tribute System of the Early Qing Dynasty]." Qingshi yanjiu 清史研究, no. 2 (2010): 86-97.

Chen Shou 陳壽. San guo zhi 三國志 [Records of the Three Kingdoms], annot. Pei Songzhi 裴松之. Beijing: Zhonghua shuju, 2000.

Chen Wenshou 陳文壽. Jinshi chuqi Riben yu Hua-Yi zhixu yanjiu 近世初期日本與華 夷秩序研究 [Research on Japan and Hua-Yi Order during the Early Modern Period]. Hong Kong: Xianggang shehui kexue chubanshe, 2002.

Chen Zhiqi 陳志奇. Zhongguo jindai waijiaoshi 中國近代外交史 [A History of Chinese Foreign Relations in the Modern Era], part. 2. Taipei: Nantian shuju, 2003.

Cranmer-Byng, J. L. "The Chinese Perception of a World Order." International Journal 24, no. 1 (1969): 166-171.

Da'nan shilu 大南實錄 [The Veritable Records of the Great South]. Tokyo: Keio Institute of Cultural and Linguistic Studies, 1961.

Danjō Hiroshi 檀上寛. Akiyo kaikin = chōkō shisutemu to Ka-I chitsujo 明代海禁=朝貢シ ステムと華夷秩序 [The Ming-Dynasty Ban on Maritime Trade, the Tributary System and Hua-Yi Order]. Kyoto: Kyoto University Academic Press, 2013.

Daqing huidian: Yongzheng chao 大清會典 - 雍正朝 [Yongzheng Period in Collected Statutes of the Great Qing]. Beijing: Xianzhuang shuju, 2006.

Fairbank, John K. "On the Ch'ing Tributary System." Journal of Asiatic Studies 6, no. 2 (1941): $135^{-246 .}$

Fairbank, John K. The Chinese World Order: Traditional China's Foreign Relations. Cambridge: Harvard University Press, 1968.

Fan Shuzhi 樊樹志. “Wanli nianjian de Chaoxian zhanzheng 萬曆年間的朝鮮戰爭 [Military Conflict in Korea during the Reign of the Wanli Emperor]." Fudan xuebao 復旦學報, no. 6 (2003): 96-102.

Fu Baichen 付百臣. “Lüelun Riben zai Dongya chaogong tixi zhong de juese he zuoyong 略論日本在東亞朝貢體系中的角色和作用 [A Brief Discussion on the Role and Function of Japan in the East Asian Tributary System]." Shehui kexue zhanxian 社會科學戰線, no. 6 (2007): 150-155. 
Fukuo Takeichirō 福尾猛市郎, ed. Nipponshi shiryō shūsei 日本史史料集成 [A Collection of Historical Materials on Japanese History]. Tokyo: Daiichi gakushūsha, 1980.

Gao Mingshi 高明士. Tianxia zhixu yu wenhuaquan de tansuo: yi Dongya gudai de zhengzhi yu jiaoyu wei zhongxin 天下秩序與文化圈的探索一以東亞古代的政治 與教育為中心 [Exploring the World Order and Cultural Sphere of China with the Political and Education Systems of Ancient East Asia at Its Core]. Shanghai: Shanghai guji chubanshe, 2008.

Gu Tinglong 顧廷龍 and Dai Yi 戴逸, ed. Li Hongzhang quanji 李鴻章全集 [The Complete Works of Li Hongzhang]. Hefei: Anhui jiaoyu chubanshe, 2008.

Guo Tingyi 郭廷以 and Li Yushu 李毓澍, ed. Qingji Zhong-Ri-Han guanxi shiliao 清季 中日韓關係史料 [Historical Records on Relations between the Late Qing, Japan, and Korea]. Taipei: Zhongyang yanjiuyuan jindaishi yanjiusuo, 1972.

Guo Tingyi 郭廷以 and Wang Yujun 王聿均, ed. Zhong-Fa-Yuenan jiaoshe dang 中法越南交涉檔 [Archives on Representations Made by China, France, and Vietnam], vol. 1. Taipei: Zhongyang yanjiuyuan jindaishi yanjiusuo, 1962.

Guoli gugong bowuyuan gugong wenxian bianji weiyuanhui 國立故宮博物院故宮 文獻編輯委員會, ed. Gongzhongdang Yongzhengchao zouzhe 宮中檔雍正朝奏 摺 [Memorials to the Emperor in the Yongzheng Imperial Archives]. Taipei: Gugong bowuyuan, 1978.

Guoli Taiwan daxue 國立台灣大學, ed. Lidai bao'an 歷代寶案 [Precious Documents of Successive Generations]. Taipei: Guoli Taiwan daxue, 1972.

Hamashita Takeshi 濱下武志, Zhu Yingui 朱蔭貴 and Ouyang Fei 歐陽菲, trans. Jindai Zhongguo de guoji qiji: Chaogong maoyi tixi yu jindai Yazhou jingjiquan 近代中國的 國際契機: 朝貢貿易體係與近代亞洲經濟圈 [International Opportunities in Modern China: The Tributary Trade System and the Modern Asian Economic Zone]. Beijing: Zhongguo shehui kexue chubanshe, 1999.

Han Dongyu 韓東育. “Hua-Yi zhixu de Dongya goujia yu zijieti neiqing 華夷秩序的 東亞構架與自解體內情 [The Structure of 'Hua-Yi Order' in East Asia and How It Self-Disintegrated]." In Cong zhoubian kan Zhongguo 從周邊看中國 [Viewing China From the Peripheries], ed. Fudan daxue wenshi yanjiuyuan 復旦大學文史研究院, 79-9o. Beijing: Zhonghua shuju, 2009.

Hanguo minzu wenhua tuijin weiyuanhui 韓國民族文化推進委員會, ed. Hanguo wenji congkan 韓國文集叢刊 [The Collected Works of Korea]. Seoul: Minzu wenhua tuijinhui, 2003 .

He Fangchuan 何芳川. “Hua-Yi zhixu lun 華夷秩序論 ['Hua-Yi Order' Theory].” Beijing daxue xuebao 北京大學學報, no. 6 (1998): 30-45.

Huang Zhilian 黃枝連. Yazhou de Huaxia zhixu: Zhongguo yu Yazhou guojia guanxi xingtai lun 亞洲的華夏秩序: 中國與亞洲國家關係形態論 [Huaxia Order in Asia: 
A Morphological Theory on Relations between China and Other Asian Countries]. Beijing: Zhongguo renmin daxue chubanshe, 1992.

Iwai Shigeki 岩井茂樹. “16-18 shiji dongya de guoji shangye yu hushi tizhi 16-18 世紀東亞的國際商業與互市體制 [The International Business and Mutual Trade System in East Asia from the Sixteenth to Eighteenth Century]." Higashi-Ajia kenkyū 東アジア研究 46 (2006): 3-24.

Jeong In Ji 鄭麟趾. Gaoli shi 高麗史 [A History of Korea]. Tokyo: Kokusho kankōkai, 1908.

Jeong Yong Hwa 鄭容和. “Cong zhoubian shijiao lai kan chaogong guanxi: Chaoxian wangchao dui chaogong tixi de renshi he liyong 從周邊視角來看朝貢關係: 朝鮮王 朝對朝貢體系的認識和利用 [Viewing the Tributary Relationship from a Peripheral Perspective: The Joseon Dynasty's Understanding and Utilization of the Tributary System]." Guoji zhengzhi yanjiu 國際政治研究, no. 1 (2006): 72-87.

Kim, Key-Hiuk. The Last Phase of the East Asian World Order: Korea, Japan, and the Chinese Empire, 1860-1882. Berkeley: University of California Press, 1981.

Kimiya Yasuhiko 木宮泰彦. Hu Xinian 胡錫年, trans. Ri-Zhong wenhua jiaoliu shi 日 中文化交流史 [A History of Cultural Exchange between Japan and China]. Beijing: Shangwu yinshuguan, 1980.

Kyōto shiseki-kai 京都史蹟会, ed. Hayashi Razan bunshū 林羅山文集 [Collected Works of Hayashi Razan]. Kyoto: Heian kōkogaku-kai, 193 .

Lee Man Un 李萬運.Zengbuwenxian beikao 增補文獻備考 [Reference on Supplementary Documents]. Seoul: Myeongmundang, 1959.

Li Dalong 李大龍. “Butong fanshu tixi de chongzu yu wangchao jiangyu de xingcheng 不同藩屬體系的重組與王朝疆域的形成 [The Restructuring of Different Vassal Systems and the Formation of Imperial Territories]." Zhongguo bianjiang shidi yan$j i u$ 中國邊疆史地研究, no. 1 (2006): 14-23.

Li Dalong 李大龍. “Guanyu fanshu tizhi de jige lilun wenti: dui Zhongguo gudai jiangyu lilun fazhan de lilun chanshi 關於藩屬體制的幾個理論問題一對中國古代 疆域理論發展的理論闡釋 [Some Theoretical Issues Related to the Vassal System: A Theoretical Interpretation of the Development of Ancient Chinese Periphery Theory]." Xuexiyu tansuo 學習與探索, no. 4 (2007): 223-231.

Liu Xu 劉昫 et al. Jiu Tang shu 舊唐書 [Old Book of Tang]. Beijing: Zhonghua shuju, 2000.

Liu Yuewu 柳获武. "Qingdai zhongqi yiqian Zhong-Chao zongfan guanxi xia de sifa yunzuo zhi yanjiu 清代中期以前中朝宗藩關係下的司法運作之研究 [Research into the Judicial Operations of the Chinese Imperial Court in the Context of Pre-Mid-Qing-Dynasty Vassal Relations]." Fujian shifan daxue xuebao 福建師範大 學學報, no. 2 (2007): 94-101.

Ming shilu 明實錄 [The Veritable Records of the Ming Dynasty]. Taipei: Zhongyang yanjiuyuan lishi yuyan yanjiusuo, 1962. 
Miyata Toshihiko 宮田俊彦. Ryūmin Ryūshin kōshō-shi no kenkyū 琉明・琉清交渉史の 研究 [Research on the History of Diplomatic Representations between Ryukyu and the Ming and Qing Courts]. Tokyo: Bungaku shuppan, 1996.

Peyrefitte, Alain. Tingzhi de diguo 停滯的帝國 [The Immobile Empire], trans. Wang Guoqing 王國卿. Shanghai: Sanlian shudian, 1993.

Phan Thúc Trực 潘叔直, ed. Guoshi yibian: Mingming zhengyao: Rouyuan 國史遺編. 明命政要·柔遠 [Remnants of the History of the Nation: Political Events of the Ming Dynasty: Pacification of the Distant Regions]. Hong Kong: New Asia Institute of Advanced Chinese Studies, the Chinese University of Hong Kong, 1965.

Qi Qizhang 戚其章. “Riben tunbing Liuqiu yu Zhong-Ri guanyu qiuan de jiaoshe 日本 吞併琉球與中日關於球案的交涉 [Japan's Annexation of Ryukyu and Diplomatic Representations Made by China and Japan about Ryukyu]." Jinan jiaoyu xueyuan xuebao 濟南教育學院學報, no. 5 (2000): 1-8.

Qing shilu 清實錄 [The Veritable Records of the Qing Dynasty]. Vols. 186, 245.

Riben waijiao wenshu 日本外交文書 [Diplomatic Documents ofJapan], 11. 271-272.

Robinson, Kenneth R. "Centering the King Chosõn: Aspects of Korean Maritime Diplomacy, 1392-1592." Journal of Asian Studies 59, no. 1 (February 200o): 109-125.

Rossabi, Morris. China and Inner Asia: From 1368 to the Present Day. London: Pica Press, 1975.

Seung Moon Won 承文院. Tongwen huikao 同文彙考 [Verifications of Collected Texts]. Seoul: Gugsapyeonchan-wiwonhoe, 1978.

Shang Huipeng 尚會鵬. "Lunren yu tianxia: jiedu yi chaogong tixi wei hexin de gudai dongya guoji zhixu 倫人與天下: 解讀以朝貢體系為核心的古代東亞國際秩序 ['Lunren' and 'Tianxia': Deciphering the International Order of Ancient East Asia with the Tributary System at Its Core]." Guoji zhengzhi yanjiu, no. 2 (2009): 29-43.

Shao Xunzheng 邵循正. Zhong-Fa-Yuenan guanxi shimo 中法越南關係始末 [Relations between China, France, and Vietnam]. Shijiazhuang: Hebei jiaoyu chubanshe, 2000.

Sima Qian 司馬遷. Shiji 史記 [Records of the Grand Historian]. Beijing: Zhonghua shuju, 2000.

Singer, Aubery. The Lion and the Dragon: The Story of the First British Embassy to the Court of the Emperor Qianlong in Peking 1792-94. London: Barrie \& Jenkins, 1992.

Spence, Jonathan, and John Wills, Jr., ed. From Ming to Qing: Conquest, Region and Continuity in Seventeenth-Century China. New Haven: Yale University Press, 1979.

Tang Xiyong 湯熙勇. “Qing Shunzhi zhi Qianlong shiqi Zhongguo jiuzhu Chaoxian hainanchuan ji piaoliumin de fangfa 清順治至乾隆時期中國救助朝鮮海難船及漂 流民的方法 [How China Provided Relief to Korean Vessels and Individuals Affected by Maritime Disasters from the Reigns of the Shunzhi Emperor to the Qianlong Emperor of the Qing dynasty].” In Zhongguo haiyang fazhanshi lunwenji 中國海洋 發展史論文集 [Collected Papers on the Maritime History of China], 8.105-172. Taipei: Zhongyang yanjiuyuan zhongshan renwen shehui kexue yanjiusuo, 2002. 
Tuo Jin 托津, ed. Qing huidian shili 清會典事例 [Examples of Qing Dynasty Statutes]. Beijing: Zhonghua shuju, 1991.

Virphol, Sarasin. Tribute and Profit: Sino-Siamese Trade, 1652-1853. Cambridge: Harvard University Press, 1977.

Wang Cungang 王存綱 and Liu Han 劉涵. “Chaogong tixi xia gudai Dongya zhixu xingcheng yu weixi de neizai luoji 朝貢體系下古代東亞秩序形成與維繫的內在邏 輯 [The Internal Logic behind the Formation and Maintenance of Order in East Asia during Antiquity under the Tributary System]." Guoji anquan yanjiu 國際安全 研究, no. 4 (2013): 145-155.

Wang Tieya 王鐵崖, ed. Zhongwai jiu yuezhang huibian 中外舊約章彙編 [A Compilation of Old International Treaties between China and Other Countries]. Beijing: Sanlian shudian, 1957.

Wang Yanjie 王燕傑. “Shixi Qianlong ershijiu nian de Shengjing huishen: jian lun Shengjing huishen yu Fenghuang cheng huishen de chayi 試析乾隆二十九年的 盛京會審:兼論盛京會審與鳳凰城會審的差異 [A Tentative Analysis of the Joint Trials Held in Shengjing in the 29th Year of the Reign of the Qianlong Emperor and a Discussion of Differences between the Joint Trials of Shengjing and Those of Fenghuangcheng].” Shehui kexue jikan 社會科學輯刊, no. 4 (2011): 146-151.

Wen Qing 文慶, Jia Zhen 賈楨 and Bao Yun 寶栓金 et al., ed. “Chouban yiwu shimo 籌辦夷務始末 [Foreign Affairs of the Late Qing Dynasty].” In Xuxiu siku quanshu 續修 四庫全書 [A Continuation of the Complete Library of the Four Treasrties], Daoguang era 道光朝, 416.73.31-33. Shanghai: Shanghai guji chubanshe, 1996.

Xie Bizhen 謝必震. Ming-Qing Zhong-Liu hanghai maoyi yanjiu 明清中琉航海貿易研 究 [Research into Ryukyu Navigation and Trade during the Ming and Qing Dynasties]. Beijing: Haiyang chubanshe, 2004.

$\mathrm{Yu}$ Xiaoguang 於曉光. "Mingchao yu Chaoxian weirao Nüzhenren de jiaoshe wenti yanjiu 明朝與朝鮮圍繞女真人的交涉問題研究 (1368-1619) [Research on Diplomatic Representations between the Ming Imperial Court and Korea Regarding the Jurchens]." PhD diss., Shandong University, 2006.

Yue Yang 岳陽. “Qing-Xian guanxi zhong de Chaoxian jizixing yanjiu 清鮮關係中 的朝鮮齊咨行研究 [Research into Korean Jaejahaeng Envoys in the Context of Qing-Korean Relations].” Master's thesis, Shandong University, 2010.

Zhang Cunwu 張存武. “Zhongguo dui xifang kuisi Liuqiu de fanying 中國對西方窺伺 琉球的反應, 1840-186o [China's Reaction to the West's Gaze on Ryukyu]." Jindaishi yanjiusuo jikan 近代史研究所集刊 16 (1987): 85-110.

Zhang Shengzhen 張聲振 and Guo Hongmao 郭洪茂. Zhong-Ri guanxishi 中日關係史 [A History of Sino-Japanese Relations]. Beijing: Shehui kexue wenxian chubanshe, 2006.

Zhang Tingyu 張廷玉 et al. Mingshi 明史 [The Official History of the Ming Dynasty]. Beijing: Zhonghua shuju, 2000. 
Zheng Liangsheng 鄭樑生, ed. Ashita kankei-shi no kenkyū 明日関係史の研究 [Research on Relations between the Ming Dynasty and Japan]. Tokyo: Yuzankaku, 1995.

Zhongguo di yi lishi dang'anguan 中國第一歷史檔案館, ed. Qingdai Zhong-Chao guanxi dang'an shiliao xubian 清代中朝關係檔案史料續編 [Continuation of Historical Archives on Relations between China and Korea during the Qing Dynasty]. Beijing: Zhongguo dang'an chubanshe, 1998.

Zhongguo shixuehui 中國史學會, ed. Zhong-Fa zhanzheng 中法戰爭 [The Sino-French War], vol. 1. Shanghai: Shanghai renmin chubanshe, 1957.

Zhou Fangyin 周方銀 and Gao Cheng 高程, ed. Dongya zhixu: guannian, zhidu yu zhanlüe 東亞秩序: 觀念, 制度與戰略 [East Asian Order: Concepts, Systems, and Strategies]. Beijing: Shehui kexue wenxian chubanshe, 2012.

Zhuang Guotu 莊國土. “Lüelun chaogong zhidu de xuhuan: yi gudai Zhongguo yu Dongnanya de chaogong guanxi wei li 略論朝貢制度的虛幻: 以古代中國與東 南亞的朝貢關係為例 [A Brief Discussion on the Illusion of the Tributary System as Demonstrated by the Tributary Relations between China and East Asia during Antiquity]." Nanyang wentiyanjiu 南洋問題研究, no. 3 (2005): 1-8. 